\title{
PENDAMPINGAN PENGELOLAAN KAMPUNG WOLULAS, KECAMATAN TUREN, KABUPATEN MALANG SEBAGAI KAMPUNG WISATA EDUKASI
}

\section{ACCOMPANIMENT MANAGEMENT OF WOLULAS VILLAGE, SUB-DISTRICT OF TUREN, DISTRICT OF MALANG AS A VILLAGE TOURISM OF EDUCATION}

\author{
O Sukmana ${ }^{1 a}$, V Salviana ${ }^{2}$, D. S. W. Hidayat ${ }^{1}$ \\ ${ }^{1}$ Universitas Muhammadiyah Malang \\ aKorespondensi:Oman Sukmana; E-mail: oman@umm.ac.id \\ (Diterima: 19-12-2019; Ditelaah: 20-12-2019; Disetujui: 14-09-2020)
}

\begin{abstract}
The activity aims to help the people of Wolulas village, Turen village, Malang regency in managing the Wolulas village program as an education tourism village. The method of activities is carried out through training and assistance that covers aspects of production management, marketing, finance, and environmental management which includes the arrangement of environmental parks, management of waste into organic fertilizer, and arrangement of organic waste bins, as well as assistance in tools to support the development of cake businesses and management activities Garbage Bank. The main output of this activity is in the form of product packaging cakes (sponge) and various instant drinks. The main target of this activity is the residents of Wolulas village, Turen village, Malang regency which includes women, youth, and community leaders. The results of the activity had a positive impact on the Wolulas Campus community, Turen Village in the form of: (1) increasing the variety of cake making skills for women, (2) increasing the knowledge and ability to study the internet for Youth Organization, (3) Increasing bookkeeping capabilities for the management of Waste Bank, (4) Increased knowledge and ability in making organic plants, and (5) Increased knowledge and ability in managing the social environment for community administrators. Keywords : Assistance, Management, Kampung Wolulas, Educational Tourism.
\end{abstract}

\begin{abstract}
ABSTRAK
Kegitan bertujuan untuk membantu masyarakat RW 18, Kelurahan Turen, Kabupaten Malang dalam pengelolaan program Kampung Wolulas sebagai Kampung Wisata Edukasi. Metode kegiatan dilakukan melalui pelatihan (training) dan pendampingan yang meliputi aspek manajemen produksi, pemasaran, keuangan, dan pengelolaan lingkungan yang meliputi penataan taman lingkungan, pengelolaan sampah menjadi pupuk organic, dan penataan tempat sampah organic,serta bantuan alat untuk mendukung pengembangan usaha kue dan kegiatan pengelolaan Bank Sampah. Luaran utama kegiatan ini adalah berupa kemasan produk kue (bolu) dan aneka minuman instan. Sasaran utama kegiatan ini adalah warga RW 18, Kelurahan Turen, Kabupaten Malang yang meliputi ibu-ibu anggota PKK RW, Karang Taruna, dan Tokoh Masyarakat. Hasil kegiatan memberikan dampak yang positif bagi masyarakat Kampus Wolulas, RW 18, Kelurahan Turen berupa: (1) peningkatan keterampilan variasi pembuatan kue bagi ibu-ibu PKK, (2) peningkatan pengetahuan dan kemampuan mengela internet bagi Karang Taruna, (3) Peningkatan kemampuan pembukuan bagi pengurus Bank Sampah, (4) Peningkatan pengetahuan dan kemampuan dalam membuat tanaman organic, dan (5) Peningkatan pengetahuan dan kemampuan dalam pengelolaan lingkungan sosial bagi pengurus RW.
\end{abstract}

Kata Kunci : Pendampingan, Pengelolaan, Kampung Wolulas, Wisata Edukasi. 
Sukmana, O., Salviana, V., \& Hidayat, D. W. (2020). Pendampingan Pengelolaan Kampung Wolulas, Kecamatan Turen, Kabupaten Malang Sebagai Kampung Wisata Edukasi. Jurnal Qardhul Hasan : Media Pengabdian kepada Masyarakat, 6(2), 134-144.

\section{PENDAHULUAN}

Pembangunan berbasis masyarakat secara sederhana dapat diartikan sebagai pembangunan yang mengacu kepada kebutuhan masyarakat, direncanakan, dan dilaksanakan oleh masyarakat dengan sebesar-besarnya memanfaatkan potensi sumberdaya (alam, manusia, kelembagaan, nilai-nilai sosial budaya, dan lain-lain) yang ada dan dapat diakses oleh masyarakat setempat (Theresia, dkk., 2014: 28). Oleh karena itu, pembangunan berbasis masyarakat seharusnya pembangunan berangkat dari kebutuhan masyarakat dan bukannya dirumuskan oleh "orang luar" atau elit masyarakat. Pembangunan berbasis masyarakat berarti pembangunan harus berbasis pada sumberdaya local, modal sosial lokal, budaya local, kearifan local, dan modal spiritual yang dimiliki oleh masyarakat setempat. Pemberdayaan masyarakat merupakan sebuah paradigm baru dalam pembangunan, yakni yang bersifat people-centered, participatory, empowering, and sustainable.

Upaya pemberdayaan masyarakat dilakukan oleh warga masyarakat di lingkungan Rukun Warga (RW) 18, Kelurahan Turen, Kabupaten Malang, melalui program pengelolaan lingkungan yang diberi nama Kampung Wolulas sebagai Kampung Wisata dan Edukasi. Program Kampung Wolulas sebagai Kampung Wisata dan Edukasi berbasis potensi modal sosial dan modal lingkungan local yang dikembangkan untuk meningkatkan kesejahteraan masyarakat. Konsep Kampung Wolulas pada awalnya digagas oleh seorang wanita bernama Dr. Sita Acetylena, M.Pd., yang bekerjasama dengan Universitas Islam Raden Rahmat (UNIRA) Malang, STIEKN Jayanegara Malang, Taman Siswa Malang, Kiraku Training and Education Centre, dan Turen Indah Group.
Peresmian kampong Wolulas sebagai kampong edukasi (Bahasa) dilaksanakan pada tanggal 28 Oktober 2017 yang dipusatkan di lapangan Kecamatan Turen, Kabupaten Malang, Jawa Timur.

Gambar 1. Peresmiaan Program Kampung Woluas.

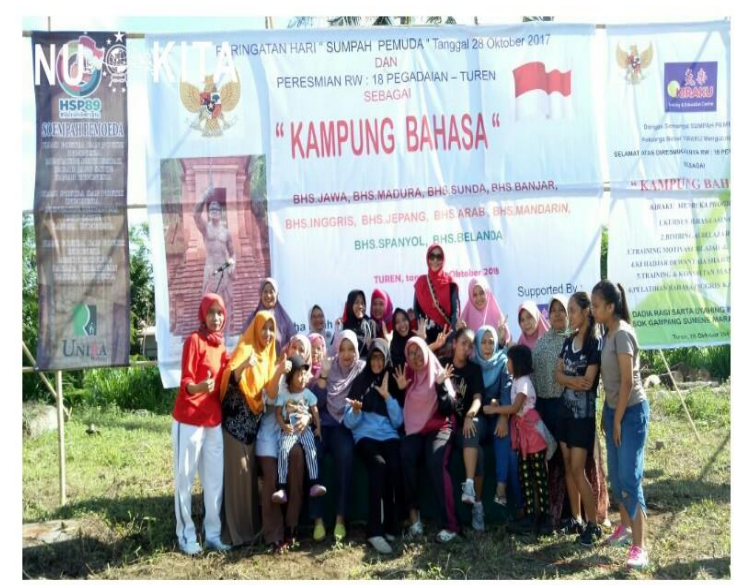

Program utama Kampung Wolulas difokuskan kepada dua hal, yakni pengembangan Kampung Wisata Edukasi dan pengembangan Kampung Bahasa. Program pengembangan Kampung Wisata Edukasi diarahkan kepada upaya melakukan pendidikan dan pelatihan kepada masyarakat khususnya di lingkungan RW 18, Kelurahan Turen, Kabupaten Malang agar mampu mengelola lingkungan, seperti pengelolaan taman, penanaman bunga hias, dan sebagainya, dan membuat berbagai produk usaha ciri khas Kampung Masyarakat Wolulas, seperti kue kering, bolu Brownis, minuman kopi, dan sebagainya.

Kelurahan Turen termasuk ke dalam bagian wilayah Kecamatan Turen, Kabupaten Malang, terletak pada 8,1028 LS dan 112,4158 BT dengan total luas wilayah 382,50 Ha yang terdiri dari 105,30 Ha lahan sawah dan 531,07 Ha lahan kering. Batas Wilayah Turen adalah sebagai berikut: sebelah Barat desa Tanggung dan Desa Jeru, sebelah Selatan Desa Sedayu, sebelah Utara Desa Kedok dan Pagedangan, dan sebelah Timur Desa Talok. jumlah penduduk 
Kelurahan Turen adalah sebanyak 14025 jiwa dengan jumlah Kepala Keluarga (KK) sebanyak $3013 \mathrm{KK}$.

\section{MATERI DAN METODE}

\section{Metode pelaksanaan Kegiatan:}

Untuk mencapai target/sasaran luaran kegiatan, maka metode pelaksanaan kegiatan dilakukan melalui tiga metode, yakni: (1) Pelatihan, (2) Pendampingan, dan (3) Bantuan Barang. Penjelasan ketiga metode tersebut adalah sebagai berikut:

\section{Pertama: Metode pelatihan}

Metode ini dilaksanakan sebagai upaya dalam meningkatkan kemampuan dan keterampilan warga masyarakat Kampung Wolulas (RW 18), Kelurahan Turen, Kecamatan Turen, Kabupaten Malang. Pelatihan yang diberikan meliputi: (1) pelatihan variasi produk kue, (2) system jaringan pemasaran online, (3) pengelolaan bank sampah menjadi pupuk organic, dan (4) pengenalan dan pengelolaan bank sampah.

\section{Kedua: Metode Pendampingan}

Metode ini dilaksanakan sebagai upaya dalam optimalisasi kegiatan yang sudah berjalan di masyarakat Kampung Wolulas (RW 18), Kelurahan Turen, Kecamatan Turen, Kabupaten Malang. Kegiatan tersebut memang sudah berjalan namun perlu lebih ditingkatkan lagi pengetahuan dan keterampilan masyarakat dalam menjaga keberlangsungan kegiatan tersebut. Kegiatan pendampingan yang dilakukan meliputi: (1) system pembukuan, (2) system penataan lingkungan, dan (3) pembuatan kemasan produk.

\section{Ketiga: Metode Bantuan}

Metode ini dilaksanakan dalam upaya mendukung fasilitasi sarana yang dibutuhkan oleh masyarakat dalam upaya mendukung program kegiatan pemberdayaan masyarakat. Bantuan barang yang diberikan berupa: (1) bantuan barang berupa Oven untuk mendukung aktivitas pembuatan produk kue dan makanan olahan; (2) bantuan barang berupa alat timbangan sampah untuk mendukung kegiatan operasional ibu-ibu PKK dalam pengelolalaan Bank Sampah; dan (3) Bantuan barang berupa buku cetak Bank Sampah untuk mendukung administrasi pengelolaan Bank Sampah yang dikelola oleh ibu-ibu PKK. Selanjutnya gambaran ketiga metode tersebut dapat dilihat pada tabel sebagai berikut:

Tabel 1. Metode Pelaksanaan Kegiatan

\begin{tabular}{|c|c|c|c|}
\hline No & $\begin{array}{l}\text { Metode } \\
\text { Pelaksa- } \\
\text { naan }\end{array}$ & Jenis & Sasaran \\
\hline \multirow[t]{4}{*}{1.} & \multirow[t]{4}{*}{ Pelatihan } & $\begin{array}{l}\text { 1. Variasi produk } \\
\text { kue. }\end{array}$ & $\begin{array}{l}\text { Anggota } \\
\text { PKK }\end{array}$ \\
\hline & & $\begin{array}{l}\text { 2. Sistem Jaringan } \\
\text { pemasaran } \\
\text { online. }\end{array}$ & $\begin{array}{l}\text { Karang } \\
\text { Taruna }\end{array}$ \\
\hline & & $\begin{array}{l}\text { 3. Pengolahan } \\
\text { sampah menjadi } \\
\text { pupuk organic. }\end{array}$ & $\begin{array}{l}\text { Anggota } \\
\text { PKK, } \\
\text { Karang } \\
\text { Taruna, } \\
\text { dan } \\
\text { Warga } \\
\text { lainya } \\
\text { (bapak- } \\
\text { bapak) }\end{array}$ \\
\hline & & $\begin{array}{l}\text { 4. Pengenalan dan } \\
\text { pengelolaan } \\
\text { Bank Sampah }\end{array}$ & $\begin{array}{l}\text { Anggota } \\
\text { PKK, } \\
\text { Karang } \\
\text { Taruna, } \\
\text { dan } \\
\text { Warga } \\
\text { lainya } \\
\text { (bapak- } \\
\text { bapak) }\end{array}$ \\
\hline \multirow[t]{3}{*}{2.} & \multirow[t]{3}{*}{$\begin{array}{l}\text { Pendampi } \\
\text { ngan }\end{array}$} & $\begin{array}{l}\text { 1. Sistem } \\
\text { pembukuan } \\
\text { Bank Sampah }\end{array}$ & $\begin{array}{l}\text { Anggota } \\
\text { PKK }\end{array}$ \\
\hline & & $\begin{array}{l}\text { 2. Penataan } \\
\text { lingkungan }\end{array}$ & $\begin{array}{l}\text { Anggota } \\
\text { PKK, } \\
\text { Karang } \\
\text { Taruna, } \\
\text { dan } \\
\text { Warga } \\
\text { lainya } \\
\text { (bapak- } \\
\text { bapak) }\end{array}$ \\
\hline & & 3. Pembuatan & Karang \\
\hline
\end{tabular}




\begin{tabular}{|c|c|c|c|}
\hline & & $\begin{array}{l}\text { kemasan } \\
\text { produk. }\end{array}$ & Taruna \\
\hline \multirow[t]{3}{*}{3.} & \multirow[t]{3}{*}{$\begin{array}{l}\text { Bantuan } \\
\text { Barang }\end{array}$} & $\begin{array}{l}\text { 1. Bantuan Barang } \\
\text { Oven }\end{array}$ & \multirow[t]{3}{*}{$\begin{array}{l}\text { Ibu-ibu } \\
\text { PKK }\end{array}$} \\
\hline & & $\begin{array}{l}\text { 2. Bantuan Barang } \\
\text { Timbangan } \\
\text { Sampah }\end{array}$ & \\
\hline & & $\begin{array}{ll}\text { 3. } & \text { Bantuan Buku } \\
\text { Rekening Bank } \\
\text { Sampah }\end{array}$ & \\
\hline
\end{tabular}

\section{HASIL DAN PEMBAHASAN}

Kegiatan ini dilaksanakan secara bertahap melalui 5 langkah kegiatan, yakni meliputi: (1) Kegiatan Awal, (2) Kegiatan Pelatihan, (3) Kegiatan Pendampingan, (4) Kegiatan Pemberian Bantuan, dan (5) Kegiatan Evaluasi.

Gambar 2. Kegiatan awal isolasi kegiatan

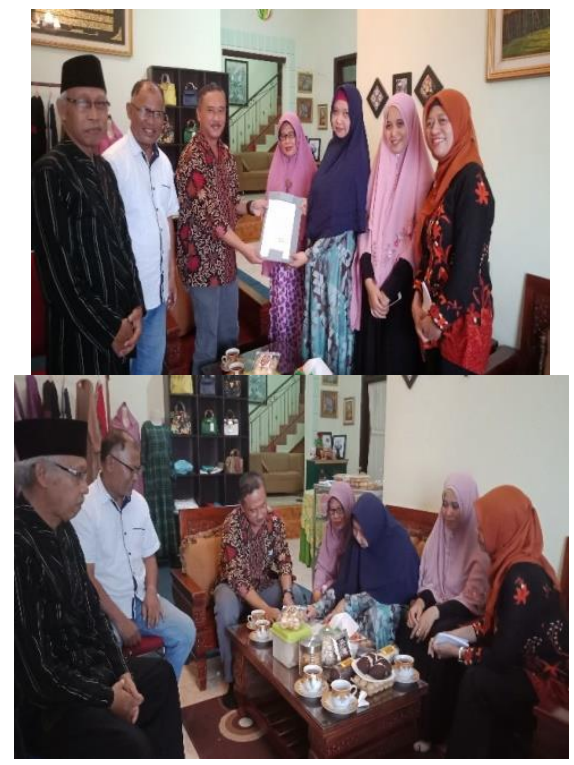

Pada gambar diatas, nampak berita acara kesepakatan kegiatan yang ditandatangani oleh ketua tim Pengabdian Kepada Masyarakat (PPM), yakni Dr. Oman Sukmana, M.S. dan Ketua Pemberdayaan Kesejahteraan Keluaraga (PKK) RW 18, Kelurahan Turen, Kecamata Turen, Kabupaten Malang, ibu Anik Widowati. Sedangkan pada gambar 3-A, berphoto bersama setelah penandatangan kesepakatan kegiatan dari kiri ke kanan: bapak Ir. H. Nurharijanto, M.MT (unsur tokoh masyarakat), bapak Hariono (Wakil Ketua I RW 18), Dr. Oman Sukmana, M.Si.
(Ketua tim PPM UMM), ibu Hj. Tasminah, S.Pd., M.Pd. (Ketua RW 18), ibu Anik Widowati (Ketua PKK RW 18), ibu Dr. Sita Acetylina, S.Pd., M.Pd. (Staf khusus RW 18), dan ibu Dr. Vinas Salviana DS, M.Si. (anggota tim PPM UMM).

\section{Kegiatan Pelatihan}

Kegiatan pelatihan yang dilakukan dalam program Pengabdian Kepada Masyarakat (PPM) ini meliputi: pelatihan pembuatan kue, pelatihan pengelolaan bank sampah, pelatihan pengolahan pupuk dan tanaman organic, pelatihan system pemasaran online.

\section{Pelatihan Pembuatan Kue}

Peserta pelatihan pembuatan aneka kue diikuti oleh peserta ibu-ibu Pemberdayaan Kesejahteraan Keluarga (PKK) RW 18, Kelurahan Turen sebanyak 10 orang. Tim Pengabdian Pada Masyarakat (PPM) menghadirkan pelatih pembuatan kue yaitu ibu Kusmiati. Kegiatan Pelatihan dilaksanakan pada hari Minggu, tanggal 23 Juni 2019 bertempat di balai RW 18, Kalurahan Turen, Kecamatan Turen. Kegiatan pelatihan pembuatan kue dapat dilihat dalam gambar sebagai berikut:

Gambar 3.Kegiatan Pelatihan Pembuatan Kue.

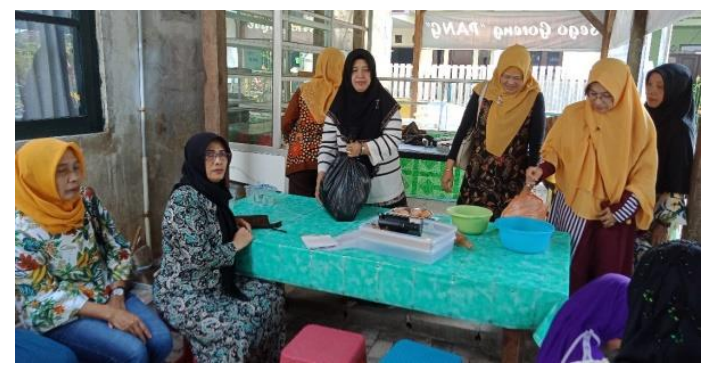

\section{Kegiatan Pelatihan Pengelolaan Bank Sampah}

Kegiatan pelatihan pengelolaan bank sampah dilaksanakan pada hari minggu tanggal 23 Juni 2019 bertempat di balai RW 18, Kelurahan Turen, Kecamatan Turen. Kegiatan ini diikuti oleh 7 orang ibu-ibu pengurus komunitas bank sampah RW 18, Kelurahan Turen. Sebagai pemateri (pelatih) adalah ibu Dr. Vina Salviana, DS., 
M.Si., sebagaimana terlihat dalam gambar berikut ini:

Gambar 4. Kegiatan Pelatihan Pengelolaan Bank Sampah.

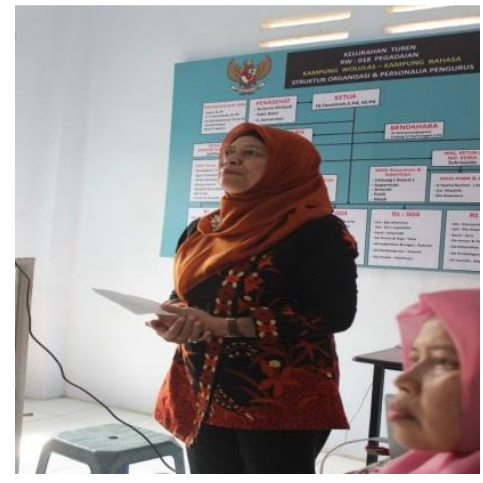

Keterangan: ibu Dr. Vina Salviana, DS., M.Si. sedang menyampaikan materi pelatihan.

\section{Kegiatan Pelatihan Pembuatan Pupuk dan Tanaman Organik}

Kegiatan pelatihan pembuatan pupuk dan tanaman organic dilaksanakan 2 kali, yakni pada hari Minggu tanggal 23 Juni 2019 dan hari Minggu tanggal 29 September 2019. Peserta kegiatan pelatihan adalah bapakbapak warga RW 18, Kelurahan Turen, Kecamatan Turen sejumlah 10 orang. Sebagai narasumber (trainer) adalah bapak Dr. Sukardi, MP., dosen Fakultas PertanianPeternakan (FPP), Universitas Muhammadiyah Malang.

\section{Gambar 5. Kegiatan Pelatihan Pembuatan} Pupuk dan Tanaman Organik

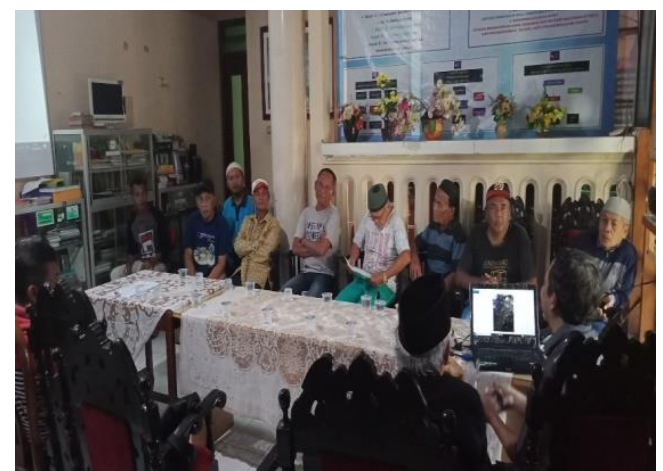

Keterangan: Bapak Dr. Sukardi, MP. (depam laptop) sedang menjelaskan cara pembuatan pupuk organic.

\section{Kegiatan Pelatihan Sistem Pemasaran Online}

Kegiatan Pelatihan Sistem Pemasaran Online diiukti oleh 15 orang anggota Karang Taruna RW 18, Kelurahan Turen, Kecamatan Turen. Kegiatan ini dilaksanakan pada hari Minggu tanggal 23 Juni 2019 bertempat di ruang pertemuan lembaga kursus dan pelatihan Kiraku, RW 18, Kelurahan Turen, Kecamatan Turen. Narasumber (trainer) kegiatan pelatihan ini adalah Moh. Afif Setiawan, ST., dari Direktorat Penelitian dan Pengabdian Kepada Masyarakat (DP2M), Universitas Muhammadiyah Malang.

Gambar 6. Kegiatan Pelatihan Sistem Pemasaran Online.

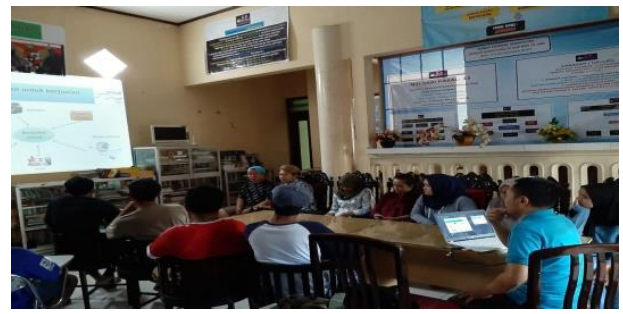

Keterangan: Kegiatan Pelatihan Pemasaran Online bagi Anggota Karang Taruna RW 18.

\section{Kegiatan Pendampingan}

Dalam kegiatan Program Pengabdian Kepada Masyarakat (PPM) ini bentuk kegiatan pendampingan yang dilakukan meliputi: pendampingan Sistem Pembukuan Bank Sampah, pendampingan pengelolaan lingkungan, dan pendampingan pembuatan kemasan produk.

Kegiatan pendampingan pembukuan bank sampah dilaksanakan pada tanggal 29 September 2019, bertempat di balai RW 18, Kelurahan Turen, Kecamatan Turen. Peserta kegiatan pendampingan sebanyak 7 orang dari pengurus komunitas Bank Sampah RW 18, Kelurahan Turen, Kecamatan Turen. Materi pendampingan meliputi tata cara pengisian dan pencatatan tabungan sampah bagi nasabah bank sampah.

Gambar 7. Pendampingan Pembukuan Bank Sampah. 


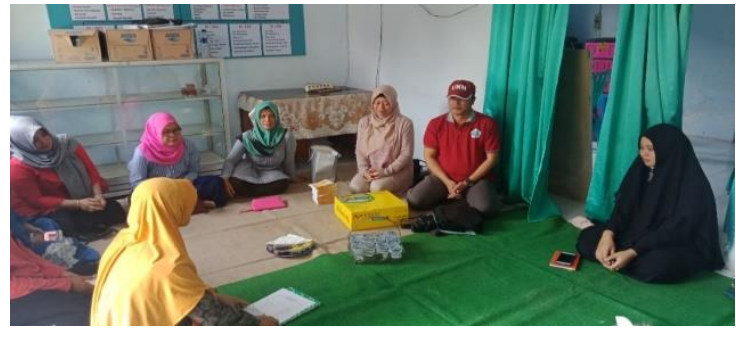

Pada gambar 7 diatas nampak tim PPM UMM sedang melakukan pendampingan pengisian buku Bank Sampah. Sedangkan pada gambar 8 dibawah adalah contoh dari buku Bank Sampah.

Gambar 8. Buku Tabungan Bank Sampah Kampung Molulas.

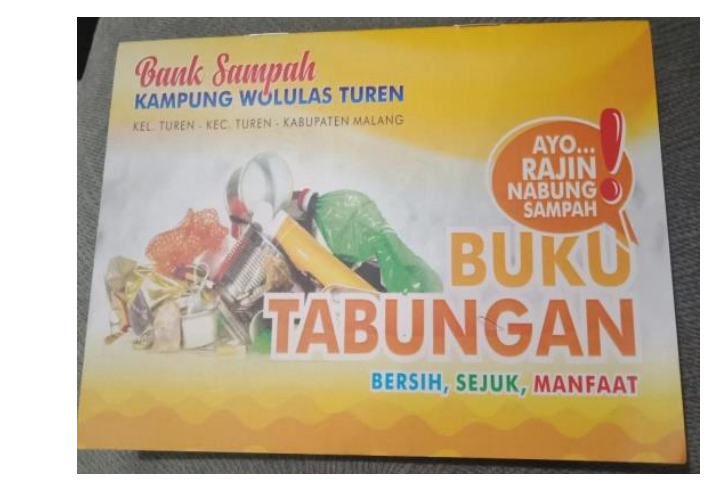

Bentuk Kegiatan pendampingan berikutnya adalah pendampingan penataan (pengelolaan) lingkungan. Nampak dalam gambar 9 di bawah ini tim PPM sedang berdiskusi dengan bapak Harioni, Wakil RW 18, Keluruhan Turen, Kecamatan Turen, tentang rencana penataan lingkungan RW 18, Kelurahan Turen, Kecamatan Turen.

\section{Gambar 9. Kegiatan Pendampingan Penataan Lingkungan}

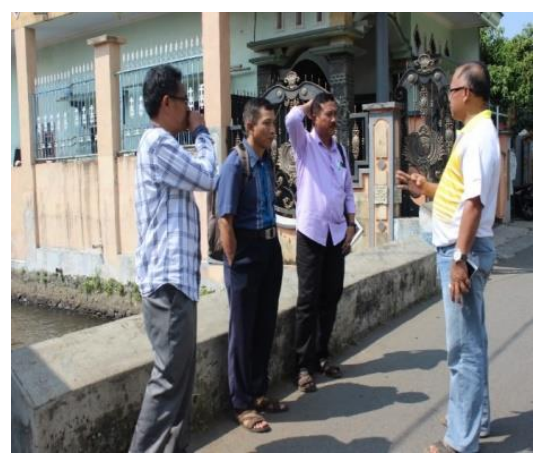

Bentuk kegiatan pendampingan berikutnya adalah pendampingan pembuatan kemasah produk. Sasaran kegiatan pendampingan adalah anggota Karang Taruna.

\section{Gambar 10.Contoh Berbagai Produk Minumen, hasil Usaha Masyarakat Kampung Wolulas.}

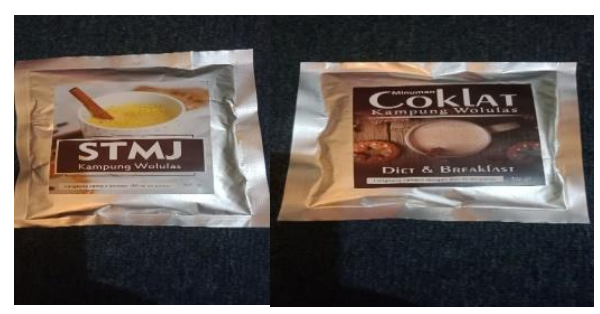

Gambar 11. Contoh Kemasan Berbagai Produk Kue, hasil Usaha Masyarakat Kampung Wolulas.

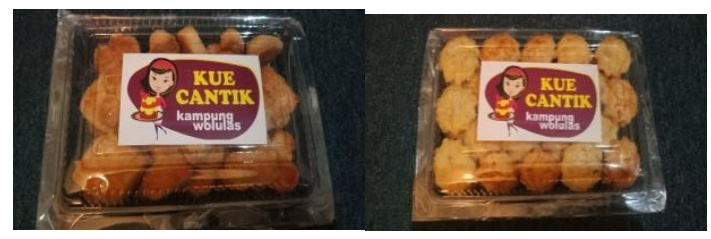

Gambar 12. Contoh Etalase Berbagai Produk Kue, hasil Usaha Masyarakat Kampung Wolulas.

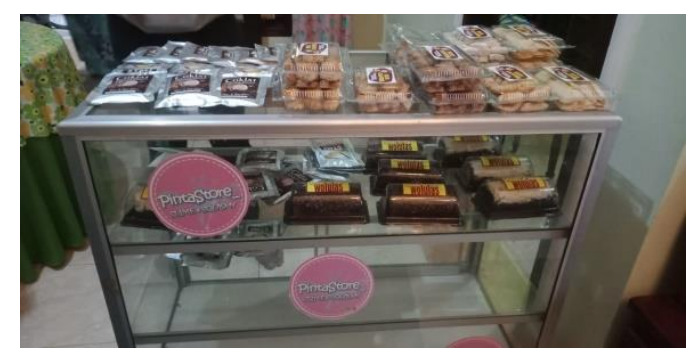

\section{Kegiatan Pemberian Bantuan Barang}

Bantuan barang yang diberikan adalah bantuan barang yang dibutuhkan oleh warga RW 18, Kelurahan Turen dalam upaya mendukung pengurus RW 18 untuk meningkatkan kesejahteraan masyarakat. Sesuai dengan kebutuhan masyarakat, maka jenis bantuan barang ini adalah berupa: Oven, Timbangan sampah, dan bantuan cetak buku tabungan Bank Sampah. 
Bantuan Oven ditujukan untuk mendukung peningkatan kapasitas produksi pembuatan kue bagi ibu-ibu PKK RW 18, Kelurahan Turen, Kecamatan Turen. Selama ini mereka hanya punya satu oven satu pintu, sehingga dibutuhkan oven yang memiliki 2 pintu. Proses penyerahan bantuan oven dilakukan pada tanggal 23 Juni 2019 kepada ketua RW 18.

Gambar 13. Kegiatan Penyerahan Bantuan Oven, Alat Timbang, dan Buku Tabungan Bank Sampah.

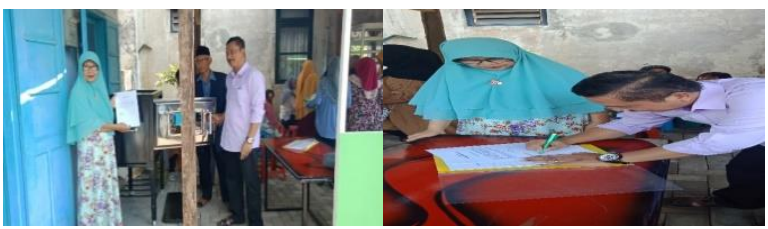

Keterangan: Proses penyerahan bantuan oven kepada ketua RW 18.

Sedangkan jenis Oven yang diberikan adalah oven 2 pintu :

Gambar 14. Bantuan Barang Berupa OVEN

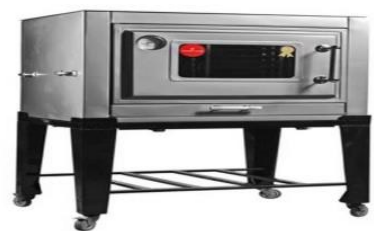

Keterangan: Gambar Oven yang diberikan oleh Tim PPM kepada warga RW 18,

Bantuan barang yang kedua adalah bantuan barang berupa alat timbangan sampah digital. Alat ini dibutuhkan oleh pengurus bank sampah RW 18 untuk menimbang sampah dari nasabah yang sekaligus muncul informasi berat sampah dan besarnya nilai rupiah. proses penyerahan bantuan alat timbangan sampah digital yang diberikan kepada ibu ketua RW 18, Keluruahan Turen pada tanggal 29 Nopember 2019 bertempat di balai RW 18, Kelurahan Turen.

Gambar 15. Kegiatan Penyerahan Bantuan Alat Timbang.

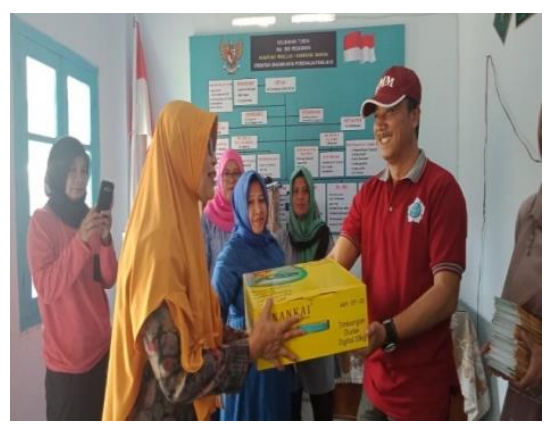

Keterangan: Proses penyerahan bantuan alat timbang sampah digital.

Sedangkan contoh gambar alat timbang sampah digital yang diberikan kepada warga RW 18.

Gambar 16. Gambar Alat Timbang Digtal

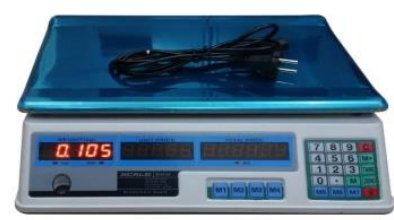

Bantuan barang yang ketiga adalah berupa buku cetak Bank Sampah. Buku Bank Sampah ini sangat diperlukan oleh pengurus Bank Sampah untuk mencatat semua transaksi setoran sampah dari nasabah. proses penyerahan bantuan buku Bank Sampah kepada ketua RW 18, Kelurahan Turen.

Gambar 17. Bantuan Buku Rekening Bank Sampah.

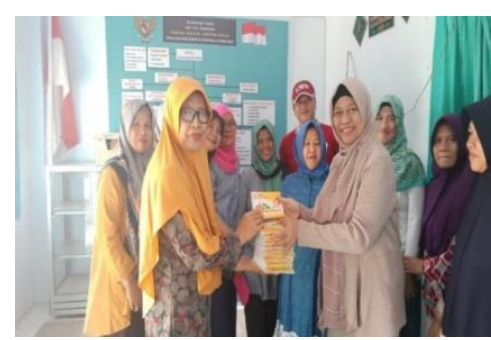

Keterangan: Proses penyerahan bantuan buku Bank Sampah

Gambar 18. Buku Tabungan Bank Sampah 


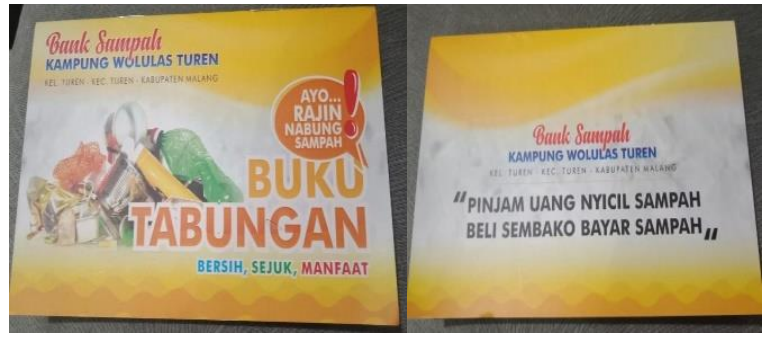

Keterangan: Contoh buku Tabungan Bank Sampah

\section{Hasil Yang Dicapai}

Hasil yang dicapai dari kegiatan program Pengabdian Kepada Masyarakat (PPM) ini dapat dilihatn dalam uraia tabel sebagai berikut:

Tabel 2. Uraian Hasil Kegiatan Program PPM

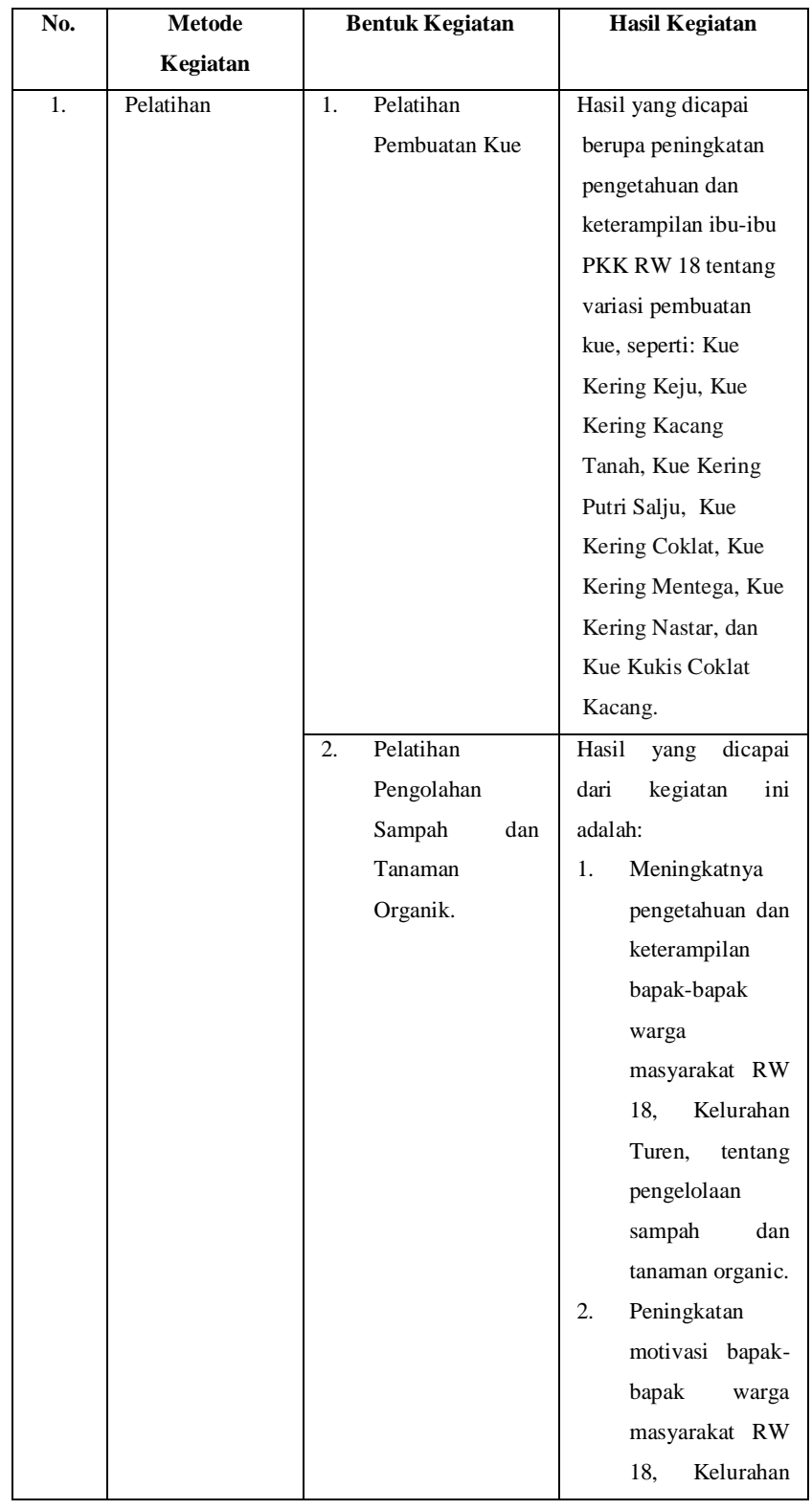

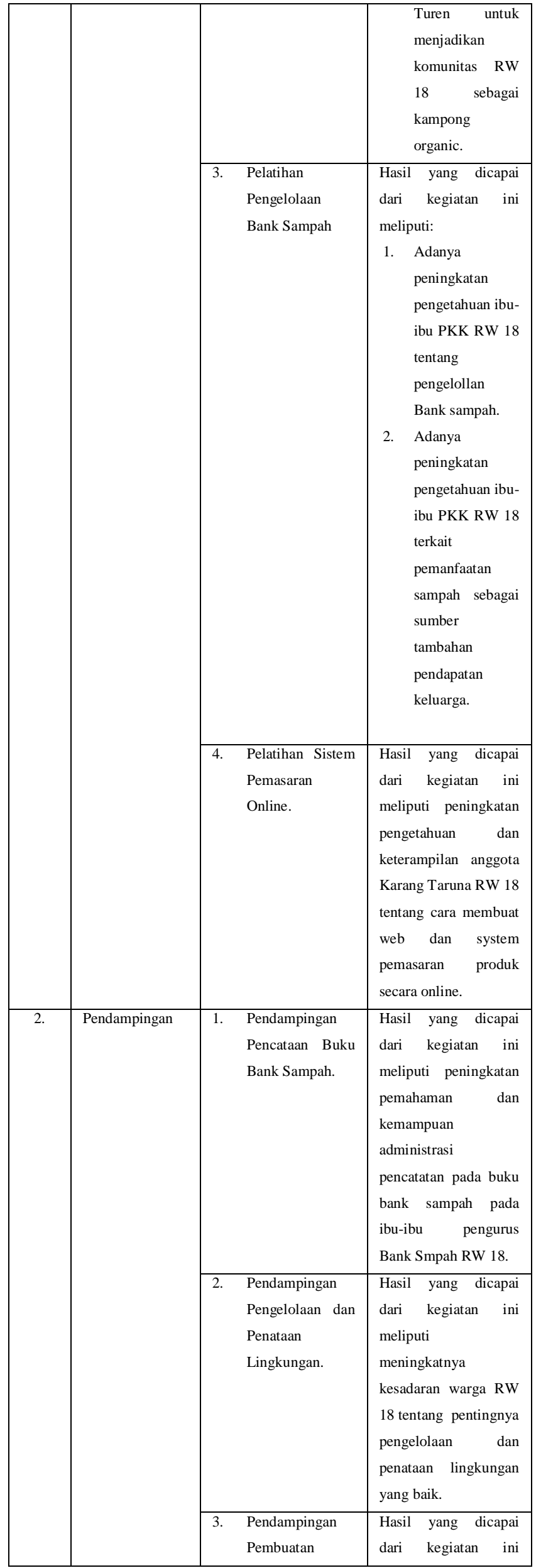




\begin{tabular}{|c|c|c|c|c|}
\hline & & & $\begin{array}{l}\text { Kemasan Produk } \\
\text { Makanan (kue). }\end{array}$ & $\begin{array}{lr}\text { meliputi peningkatan } \\
\text { pengetahuan dan } \\
\text { keterampilan pada } \\
\text { remaja } \\
\text { Karang Taruna RW } 18 \\
\text { tentang } \\
\text { pembuatan kemasan } \\
\text { produk makanan dan } \\
\text { minuman. }\end{array}$ \\
\hline \multirow[t]{3}{*}{3.} & \multirow[t]{3}{*}{ Bantuan Barang } & 1. & Bantuan Oven & $\begin{array}{l}\text { Bantuan } \\
\text { berupa } \\
\text { mendukung } \\
\text { peningkatan kapasitas } \\
\text { produksi kue bagi ibu- } \\
\text { ibu RW 18. }\end{array}$ \\
\hline & & & $\begin{array}{l}\text { Bantuan Alat } \\
\text { Timbangan } \\
\text { Sampah Digital }\end{array}$ & $\begin{array}{l}\text { Pemberian bantuan } \\
\text { alat timbang sampah } \\
\text { digital membantu } \\
\text { kerja pengurus bank } \\
\text { sampah RW } 18 \text {. }\end{array}$ \\
\hline & & & $\begin{array}{l}\text { Bantuan Cetak } \\
\text { Buku Tabungan } \\
\text { Bank Sampah }\end{array}$ & 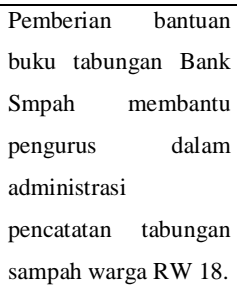 \\
\hline
\end{tabular}

\section{Pembahasan}

Upaya pemberdayaan masyarakat dilakukan oleh warga masyarakat di lingkungan Rukun Warga (RW) 18, Kelurahan Turen, Kabupaten Malang, melalui program pengelolaan lingkungan yang diberi nama Kampung Wolulas sebagai Kampung Wisata dan Edukasi. Program Kampung Wolulas sebagai Kampung Wisata dan Edukasi berbasis potensi modal sosial dan modal lingkungan local yang dikembangkan untuk meningkatkan kesejahteraan masyarakat.

Menurut Soleh $(2014,17)$ sejak tahun 1970an pemberdayaan menjadi sebuah kredo baru dalam pembangunan dan merasuk ke sleuruh sector kehidupan. Pemberdayaan (empowerment) dalam perspektif politik sering dimaknai sebagai pemberian kekuasaan. Sementara dalam perspektif sosial ekonomi pemberdayaan (empowerment) lebih dipandang sebagai upaya untuk memberi daya. Pemberdayaan adalah memberi energy agar rakyat mampu bergerak secara mandiri, sehingga dengan demikian pemberdayaan tidaklah bersifat selamanya, melainkan sampai target mampu mandiri dan kemudian lepas untuk mandiri, akan tetapi dari jauh tetap diamati dan terus dijaga agar tidak jatuh lagi. Pembangunan pada hakekatnya adalah transformasi atau perubahan menuju keadaan yang lebih baik, sementara itu pemberdayaan pada hakekatnya adalah pemberian energy agar masyarakat mampu hidup secara mandiri. Kendati kedua istilah tersebut memiliki tujuan yang sama, namun pendekatan dan strategi yang ditempuh berbeda.

Sementara menurut Theresia, dkk. (2014: 110), konsep pemberdayaan masyarakat mencakup pengertian pembangunan masyarakat (community development) dan pembangunan yang bertumpu pada masyarakat (community-based development). Pemberdayaan masyarakat adalah upaya untuk meningkatkan harkat dan martabat lapisan masyarakat untuk melepaskan diri dari perangkap kemiskinan dan keterbelakangan. Dengan kata lain pemberdayaan adalah memampukan dan memandirikan masyarakat. Pemberdayaan menunjuk pada kemampuan orang, khusunya kelompok untuk: (1) memiliki akses terhadap sumber-sumber produktif yang memungkinkan mereka dapat meningkatkan pendapatannya dan memperoleh barang-barang dan jasa-jasa yang mereka perlukan; dan (2) berpartisipasi dalam proses pembangunan dan keputusan-keputusan yang mempengaruhi mereka. Pemberdayaan menunjuk pada usaha pengalokasian kembali kekuasaan melalui pengubahan struktur sosial.

Selanjutnya, pemberdayaan dapat diartikan sebagai upaya peningkatan kemampuan masyarakat (miskin, marjinal, terpinggirkan) untuk menyampaikan pendapat dan atau kebutuhannya, pilihanpilihannya, berpartisipasi, bernegosiasi, mempengaruhi dan mengelola kelembagaan masyarakatnya secara bertanggung-gugat (accountable) demi perbaikan kehidupannya. Dalam pengertian tersebut, pemberdayaan mengandung arti perbaikan 
mutu hidup atau kesejahteraan setiap individu dan masyarakat baik dalam arti: (1) perbaikan ekonomi, terutama kecukupan pangan; (2) perbaikan kesejahteraan sosial (pendidikan dan kesehatan); (3) kemerdekaan dari segala bentuk penindasan; (4) terjaminnya keamanan; dan (5) terjaminnya hak asasi manusia yang bebas dari rasa takut dan kekhawatiran (Theresia, 2014: 117).

\section{Kendala Yang Dihadapi}

Beberapa kendala yang dihadapai dalam pelaksanaan program Pengabdian Kepada masyarakat (PPM) ini adalah antara lain sebagai berikut:

Pertama, Kegiatan hanya bisa dilaksanakan setiap hari Minggu (atau hari libur) karena sebagian besar warga masyarakat RW 18 waktunya digunakan untuk bekerja.

Kedua, Durasi waktu yang digunakan untuk kegiatan pelatihan sangat terbatas, sehingga program pelatihan tidak bisa dilakukan secara optimal. Warga masyarakat meminta untuk dilaksanakan kegiatan pelatihan secara kontinyu, misalnya pelatihan pengolahan sampah dan tanaman organic yang tidak cukup hanya 2 kali.

Ketiga, anggaran (dana) kegiatan program Pengabdian Kepada masyarakat (PPM) sangat terbatas, sementara bantuan yang dibutuhkan oleh masyarakat sangat banyak. Misalnya, bantuan Oven tidak cukup satu buha, minimal 2 atau 3 buah.

\section{KESIMPULAN}

Program Pengabdian Kepada Masyarakat (PPM) ini dilakukan dalam upaya membantu masyarakat (warga) Rukun Warga 18, Kelurahan Turen, Kecamatan Turen, Kabupaten Malang dalam mengembangkan komunitas Kampong Wolulas sebagai kampong wisata dan edukasi. Program pengebdian dilaksanakan melalui tige metode kegiatan, yakni: pelatihan, pendampingan, dan bantuan barang. Kegiatan pelatihan yang diberikan berupa: pelatihan pembuatan aneka kue, pelatihan pengelolaan sampah dan tanaman organic, pelatihan pengelollan bank sampah, dan pelatihan pembuatan system pemasaran online. Sedangkan kegiatan pendampingan yang dilakukan meliputi pendampingan: pencatatan buku bank sampah, penataan dan pengelolaan lingkungan, dan pendampingan dalam pembuatan kemasan produk kue. Sementara kegiatan bantuan barang yang diberikan berupa bantuan Oven untuk memasak kue (meningkatkan produksi kue), bantuan Timbangan Sampah Digital, dan bantuan buku cetak Bank Sampah.

\section{SARAN}

Berdasarkan hasil kegiatan program Pengabdian Kepada Masyarakat (PPM) ini, maka tim pengabdian mengusulkan saran saran sebagai berikut:

Pertama, Program pengembangan Kampung Wolulas sebagai kampong wisata edukasi sangat positif dan bermanfaat bagi masyarakat, oleh karena itu perlu terus dikembangkan;

Kedua, Pemerintah Kecamatan Turen dan Kabupaten Malang perlu terlibat secara aktif dalam memberikan keterampilan, pendampingan, dan bantuan kepada masyarakat dalam rangka pengembangan Kampung Wolulas sebagai Kampung Wisata Edukasi; dan

Ketiga, Warga masyarakat Kampung Wolulas perlu terlibat secara aktif dalam pengelolaan dan pengembangan Kampung Wolulas sebagai Kampung Wisata Edukasi.

\section{UCAPAN TERIMAKASIH}

Penulis menyampaikan ucapan terimakasih kepada semua pihak yang telah membantu dan mendukung kelancaran penelitian ini, khususnya kepada Direktur Penelitian dan Pengabdian Kepada Masyarakat (DP2M) Universitas Muhammadiyah Malang yang telah membiayai program pengabdian ini. 


\section{DAFTAR PUSTAKA}

Adi, Isbandi Rukminto. 2002. Pemikiran-Pemikiran dalam Pembangunan Kesejahteraan Sosial. Jakarta: Lembaga Penerbit FEUI.

2003. Pemberdayaan, Pengembangan Masyarakat dan Intervensi Komunitas: Pengantar pada Pemikiran dan Pendekatan Praktis. Jakarta: Lembaga Penerbit FEUI.

2007. Perencanaan Partisipatoris Berbasis Aset Komunitas: Dari Pemikiran Menuju Penerapan. Jakarta: FISIP UI Press.
2013. Kesejahteraan Sosial: Pekerjaan Sosial, Pembangunan Sosial dan Kajian Pembangunan.Jakarta: Raja Grafindo Persada.

Soleh, Chabib. 2014. Dialektika Pembangunan dengan Pemberdayaan. Bandung: FOKUSMEDIA.

Theresia, Aprillia, dkk. 2014. Pembangunan Berbasis Masyarakat: Acuan bagi Praktisi, Akedemisi, dan Pemerhati Pengembangan Masyarakat. Bandung: Alfabeta.

Theresia, Aprillia, dkk. 2014. Pembangunan Berbasis Masyarakat: Acuan Bagi Praktisi, Akademisi, dan Pemerhati Pengembangan Masyarakat. Bandung: Alfabeta. 